\title{
Consequences of Selecting Rambouillet Ewes for Mountain Big Sagebrush (Artemisia tridentata ssp. vaseyana) Dietary Preference
}

\author{
Steven S. Seefeldt \\ Author is a Rangeland Scientist, US Department of Agriculture, Agricultural Research Service, \\ US Sheep Experiment Station, Dubois, ID 83423
}

\begin{abstract}
A dense mountain big sagebrush (Artemisia tridentata Nutt. ssp. vaseyana [Rydb] Beetle) canopy suppresses understory vegetation. Rambouillet ewes with high and low dietary preferences for mountain big sagebrush were tested for their ability to reduce the cover of dense stands of sagebrush. Eighty ewes with high and low preferences for mountain big sagebrush were grazed in October on 8 pastures with a 33\% shrub cover for 3 years. Even though near infrared reflectance spectroscopy measurements of feces indicated that high-preference ewes consumed up to twice as much mountain big sagebrush than did lowpreference ewes $(P<0.005)$, there was no difference in the reduction of sagebrush canopy between the high- and lowpreference ewes $(P=0.46)$. Indeed, grazing did not reduce mountain big sagebrush more than in the ungrazed pastures. However, ewes with a high preference for mountain big sagebrush consumed more antelope bitterbrush (Purshia tridentata [Pursh] DC.) $(P<0.05)$ than did low-preference ewes (length reductions of $30 \mathrm{~cm}$ and $10 \pm 3.7 \mathrm{~cm}$ [mean \pm SE], respectively). In this study, the selection of ewes with a dietary preference for mountain big sagebrush had the unintended consequence of selecting ewes with a dietary preference for antelope bitterbrush. Antelope bitterbrush is a desirable shrub in sagebrush steppe ecosystems, and reductions in antelope bitterbrush as a result of altered livestock preferences will reduce rangeland health. Animals selected with a dietary preference for one plant species must be screened to determine what other plants they will preferentially select to limit potential negative consequences for plant communities and ecosystems.
\end{abstract}

\section{Resumen}

Una densa cobertura de copa de "Mountain big sagebrush" (Artemisia tridentata Nutt. ssp. vaseyana [Rydb] Beetle) suprime la vegetación del estrato bajo de la comunidad. Ovejas hembras Rambouillet con preferencia de dieta alta y baja para el de "Mountain big sagebrush" fueron evaluadas respecto a su capacidad de reducir la cobertura de poblaciones densas de "sagebrush". Ochenta ovejas hembras con preferencia alta y baja para el "Mountain big sagebrush" apacentaron durante tres años, en octubre, 8 potreros con un $33 \%$ de cobertura de arbustos. Aunque las mediciones de materia fecal realizadas por medio de espectroscopía cercana al infrarrojo indicaron que las hembras de alta preferencia consumieron hasta el doble de "Mountain big sagebrush" que las hembras de baja preferencia $(P<0.005)$ no hubo diferencia $(P=0.46)$ en la reducción de la copa del "Sagebrush" entre las hembras de alta y baja preferencia. De hecho, el apacentamiento no reduce el "Mountain big sagebrush" más de lo que ocurrido en los potreros sin apacentamiento. Sin embargo, las ovejas hembras con alta preferencia para el "Mountain big sagebrush" consumieron más "Antelope bitterbrush" (Purshia tridentata [Pursh] DC.) $(P<0.05)$ que las hembras de baja preferencia (reducciones de longitud de $30 \mathrm{~cm}$ y $10 \mathrm{~cm} \pm 3.7 \mathrm{DE}$, respectivamente). En este estudio, la selección de ovejas hembras con preferencia de dieta para "Mountain big sagebrush" tuvieron la consecuencia no intencional de seleccionar hembras con preferencia para el "Antelope bitterbrush". El "Antelope bitterbrush" es una especie deseable en los ecosistemas de estepas de "Sagebrush" y reducciones de esta especie debido preferencias alteradas del ganado reducirán la salud del pastizal. Animales seleccionados con una preferencia de dieta para una especie de planta deben ser examinados para determinar que otras plantas seleccionarían preferentemente y limitar las consecuencias potencialmente negativas para las comunidades de plantas y ecosistemas.

Key Words: bitterbrush, diet selection, grazing, sheep

\section{INTRODUCTION}

The use of trade, firm, or corporation names in this publication is for the information and convenience of the reader. Such use does not constitute an official endorsement or approval by the US Department of Agriculture or the Agricultural Research Service of any product or service to the exclusion of others that may be suitable.

Correspondence: Dr Steve Seefeldt, HC62 Box 2010, Dubois, ID 83423. Email: sseefeldt@pw.ars.usda.gov

Manuscript received 14 June 2004; manuscript accepted 19 January 2005
Dense sagebrush stands are associated with declines in plant diversity, increased fire risk (Johnson et al. 1996) and decreased forage production of perennial grasses and forbs (Harniss and Murray 1973; Bork et al. 1998). Most sagebrush removal methods (e.g., fire, mechanical, or herbicidal) are too uncontrollable, difficult, or expensive for land managers to use, and all have the potential for undesirable effects on the ecosystem 
(Blaisdell et al. 1982). Targeted sheep grazing could provide an alternative method for reducing sagebrush density.

Sheep are selective grazers (Grant et al. 1985), and, within a sheep breed, individual animals have different dietary preferences (Snowder et al. 2001). These differences in preference can presumably be used to manage vegetation. Within species, differences in diet selection can be a result of previous experience with a plant (Walker et al. 1992; Olson et al. 1996; Provenza 1996), grazing season (Bork et al. 1998), grazing pressure (Milne et al. 1979), and mix of plant species available to graze (Launchbaugh et al. 1990). Dietary preferences that are genetically linked have been reported for goats (Warren et al. 1983) and cattle (Winder et al. 1995).

A study at the US Sheep Experiment Station (USSES) indicated that dietary preference of Rambouillet ewes for mountain big sagebrush (Artemisia tridentata Nutt. ssp. vaseyana [Rydb] Beetle) in October had a genetic component with a heritability of 0.28 (Snowder et al. 2001). Sheep will consume sagebrush, with consumption typically increasing in the autumn. Sagebrush diet composition is estimated at $31.7 \%$ in October, with ewes with a high preference for sagebrush consuming 2 to 3 times more sagebrush than ewes with a low preference (Snowder et al. 2001). The willingness of sheep to consume increased amounts of sagebrush in the autumn has resulted in $13.9 \%$ sagebrush cover in long-term fall-grazed pastures compared with $23.5 \%$ cover in long-term springgrazed pastures in tall three-tip sagebrush (Artemisia tripartita Nutt. ssp. tripartita) at the USSES (Bork et al. 1998).

The objectives of this study were to determine whether ewes selected for a high sagebrush preference could be used to reduce sagebrush canopy and whether these ewes would have an increased preference for other shrub species.

\section{MATERIALS AND METHODS}

In the summer of 2001, an area with a dense shrub cover was selected on the USSES spring-fall range (lat $44^{\circ} 14^{\prime} 44^{\prime \prime} \mathrm{N}$, long $\left.112^{\circ} 12^{\prime} 47^{\prime \prime} \mathrm{W}\right)$. The site, at an elevation of $1800 \mathrm{~m}$, is in the northeastern part of the sagebrush steppe region (West 1983). Soils are fine-loamy, mixed, frigid Calcic Argixerolls derived from windblown loess, residuum, or alluvium on slopes ranging from $0 \%$ to $12 \%$ (Natural Resources Conservation Service 1995). Climate is semiarid with cold winters, several months of mean temperatures below freezing, and warm summers with daily highs averaging $27^{\circ} \mathrm{C}$. Annual precipitation averages 330 $\mathrm{mm}$, but during an ongoing drought, was 230,190 , and $235 \mathrm{~mm}$ for 2001, 2002, and 2003, respectively. Seventy percent of precipitation fell in the winter as snow. Mountain big sagebrush, antelope bitterbrush (Purshia tridentata [Pursh] DC.), thickspike wheatgrass (Elymus lanceolatus [Scribn. \& J.G. Sm] Gould ssp. lanceolatus), bluebunch wheat grass (Pseudoroegneria spicata [Pursh] A. Love ssp. spicata), and plains reedgrass (Calamogrostis montanensis Scribn.) dominated the vegetation.

Twelve 0.4-ha pastures $(64 \times 64 \mathrm{~m})$ were fenced, and treatments were randomly assigned. The three treatments were grazing ewes with a high preference for sagebrush, grazing ewes with a low preference, and no grazing (control). Ewes with a high and low preference for sagebrush had been identified in an earlier experiment (Snowder et al. 2001), and, of the available ewes, 40 with the highest and 40 with the lowest preference for sagebrush were selected for this experiment. To increase vegetation utilization, 10 ewes were grazed in each pasture for 8 days in 2001 and 2002, which is greater than the typical stocking rate of 16 sheep $\cdot \mathrm{d}^{-1} \cdot \mathrm{ha}^{-1}$ used in the larger pasture where this study was conducted. Because of normal herd culling, only 8 ewes were available for each pasture in 2003, so these ewes were grazed for 10 days to maintain a stocking rate consistent with previous years. Each year the ewes within a preference class were randomly placed into the appropriate treatment pastures. For 6 weeks before initiating the experiment each year, the ewes were part of a band of ewes grazing similar sagebrush steppe rangelands within $5 \mathrm{~km}$ of the study site to familiarize them with the pastures and adapt the rumen flora. During 2001, fecal samples were collected from all the study sheep and analyzed by near infrared reflectance spectroscopy (NIRS) before, during, and after grazing (Snowder et al. 2001) to determine whether these ewes continued to have the same dietary preference for sagebrush. Ewes were fed a diet of alfalfa hay for 5 days before the first fecal sampling, which served as a nonsagebrush baseline.

To measure shrub canopy, two permanent $30-\mathrm{m}$ transects were placed in each pasture that was to be grazed. Brush canopy was measured to the nearest $1 \mathrm{~cm} 1$ or 2 days before and after grazing at the point where the transect line intercepted the canopy. Canopy was defined as the green leaf material of the shrubs. Shrub species was recorded along with the canopy measurement. After grazing, any measurable reductions in the canopy along the permanent transect were classified as either a result of breakage (if the missing material was located) or other causes (deduced eaten). One permanent $30-\mathrm{m}$ transect was placed in each ungrazed pasture to measure changes in shrub cover from normal plant growth, climate, and other biotic and abiotic factors from year to year. Because of the slow growth of sagebrush and the use of permanent transects, it was determined that one transect was sufficient to measure changes in the ungrazed pastures. Indeed, during the 8-10-day grazing period, there was no measurable change in canopy in these pastures.

Experimental design was repeated measures with 4 replications (pastures) and 2 factors (sagebrush preference $[n=2]$ and years $[n=3])$. The data were determined to be normally distributed by the UNIVARIATE procedure (SAS Institute Inc, Cary, NC). A general linear models procedure was used to test for differences in mountain big sagebrush and antelope bitterbrush canopy reduction between high- and low-preference ewes, differences in grazing among years, and the interaction of years and preference (SAS). A general linear models procedure was also used to determine differences in breakage, other loss (deduced eaten), and total loss relative to treatment. To determine whether the amount of available canopy influenced diet, the data for loss were transformed to reflect this loss as a percentage of the available canopies as (sagebrush eaten/ sagebrush canopy) $\times 100$. Least significant difference was used for means separation in all analyses (SAS).

\section{RESULTS}

At the start of the experiment, overall shrub canopy was $29 \%-$ $37 \%$, with most of the canopy consisting of mountain big 
Table 1. Percent cover of shrubs (mean $\pm \mathrm{SE}$ ) in the study area on the spring-fall grazing property of the US Sheep Experiment Station before grazing was initiated. ${ }^{1}$

\begin{tabular}{|c|c|c|c|c|c|}
\hline Treatment $^{c}$ & Sagebrush & Bitterbrush & Horsebrush & Rabbitbrush & Total \\
\hline & & & --- & & ----- \\
\hline L & $24.2 \pm 2.2^{\mathrm{a}}$ & $5.6 \pm 0.5^{\mathrm{a}}$ & $0.8 \pm 0.1^{\mathrm{a}}$ & $0.2 \pm 0.1^{\mathrm{a}}$ & $30.8 \pm 3.7^{\mathrm{a}}$ \\
\hline $\mathrm{H}$ & $25.2 \pm 2.2^{a}$ & $11.3 \pm 2.4^{b}$ & $0.8 \pm 0.1^{a}$ & None & $37.3 \pm 4.7^{\mathrm{a}}$ \\
\hline C & $22.6 \pm 2.6^{a}$ & $5.3 \pm 2.0^{\mathrm{a}}$ & $0.4 \pm 0.1^{\mathrm{a}}$ & $0.6 \pm 0.1^{\mathrm{a}}$ & $28.9 \pm 2.5^{a}$ \\
\hline
\end{tabular}

${ }^{1} \mathrm{~L}$ indicates area grazed with ewes having a low preference for mountain big sagebrush; $\mathrm{H}$, area grazed with ewes having a high preference for mountain big sagebrush; and $\mathrm{C}$, no grazing. Within a column, means without a common letter are significantly different $(P<0.05)$.

sagebrush (Table 1). Pastures grazed by ewes with a high sagebrush preference by chance had twice as much antelope bitterbrush canopy than did control pastures and pastures grazed by ewes with a low preference for sagebrush. Two other shrubs, horsebrush (Tetradymia canescens DC.) and green rabbitbrush (Chrysothamnus viscidiflorus [Hook.] Nutt.), were in the pastures, but changes in canopy of these shrubs were not detected during the course of the experiment.

Estimates of the average percentage of mountain big sagebrush in the diet, measured by NIRS on fecal matter, were similar to previous estimates (Snowder et al. 2001). At the beginning in the first year of the experiment, after the sheep were fed a diet of alfalfa hay for 5 days, there were no differences in fecal NIRS. Five days into the experiment, fecal NIRS for sagebrush was $18 \%$ of their diet for low- and $23 \%$ for high-preference ewes, and the two ewe populations were different $(P<0.0001)$. At the end of the experiment, fecal NIRS was $26 \%$ for low- and $29 \%$ for high-preference ewes, and the two ewe populations were different $(P<0.005)$.

There were no differences between low- and high-preference ewes and among years for the amount of shrubs broken by the grazing ewes during the experiment (Tables 2 and 3). Breakage seemed to be a random event, and during 2001, it accounted for $<10 \%$ of the total canopy removed. The amount of mountain big sagebrush that was deduced to have been eaten decreased after the first year of the experiment (Table 2).

The total amount of mountain big sagebrush removed decreased across years from 72 to $30 \mathrm{~cm}$ (Table 2). There were no differences between pastures grazed by ewes with a low and high preference for sagebrush, and $75 \%$ of the loss was deduced to be from consumption (Fig. 1a). There was no year by preference group interaction. Each year the ewes reduced sagebrush canopy about $3 \%$. The total amount of antelope bitterbrush removed increased across years from 17 to $31 \mathrm{~cm}$

Table 2. Mountain big sagebrush (mean $\pm \mathrm{SE}$ ) removed during the sheep grazing period along the line intercept each year during the 3 years of the experiment. ${ }^{1}$

\begin{tabular}{|c|c|c|c|}
\hline Year & Broken & Other & Total \\
\hline & \multicolumn{3}{|c|}{ - } \\
\hline 2001 & $7 \pm 4.1^{\mathrm{a}}$ & $64 \pm 15.1^{\mathrm{a}}$ & $72 \pm 13.7^{\mathrm{a}}$ \\
\hline 2002 & $17 \pm 9.8^{\mathrm{a}}$ & $32 \pm 6.9^{b}$ & $49 \pm 11.4^{\mathrm{a}}$ \\
\hline 2003 & $17 \pm 7.5^{\mathrm{a}}$ & $14 \pm 2.6^{b}$ & $30 \pm 8.9^{\mathrm{a}}$ \\
\hline
\end{tabular}

${ }^{1}$ Within a column, means without a common letter are significantly different $(P<0.05)$.
Table 3. Antelope bitterbrush (mean $\pm \mathrm{SE}$ ) removed during the sheep grazing period along the line intercept each year during the 3 years of the experiment.

\begin{tabular}{llll}
\hline Year & Broken & Other & Total \\
\hline & $-0 \pm 0$ & $17 \pm 5.7$ & $17 \pm 5.7$ \\
2001 & $0 \pm 0$ & $21 \pm 5.8$ & $21 \pm 5.8$ \\
2002 & $0 \pm 0$ & $23 \pm 6.5$ & $31 \pm 8.3$ \\
2003 & $8 \pm 5.8$ & $(\mathrm{~cm})$ & \\
\hline
\end{tabular}

(Table 3). Ewes selected for high preference for mountain big sagebrush consumed or otherwise removed three times more $(P<0.05)$ antelope bitterbrush than did the ewes with a low preference for mountain big sagebrush (Fig. 1b). Because the high-preference ewes had twice as much antelope bitterbrush available to graze (Table 1), a case could be made that the highpreference ewes had more opportunity to eat the plant species compared with the low-preference ewes. When adjusted for available canopy, however, high-preference ewes removed $9.2 \% \pm .4 \%$, whereas the low-preference ewes removed $5.6 \% \pm 2 \%$ of the antelope bitterbrush canopy. Although there was no significant difference between the paddocks grazed by these two types of ewes, the trend was toward a greater removal
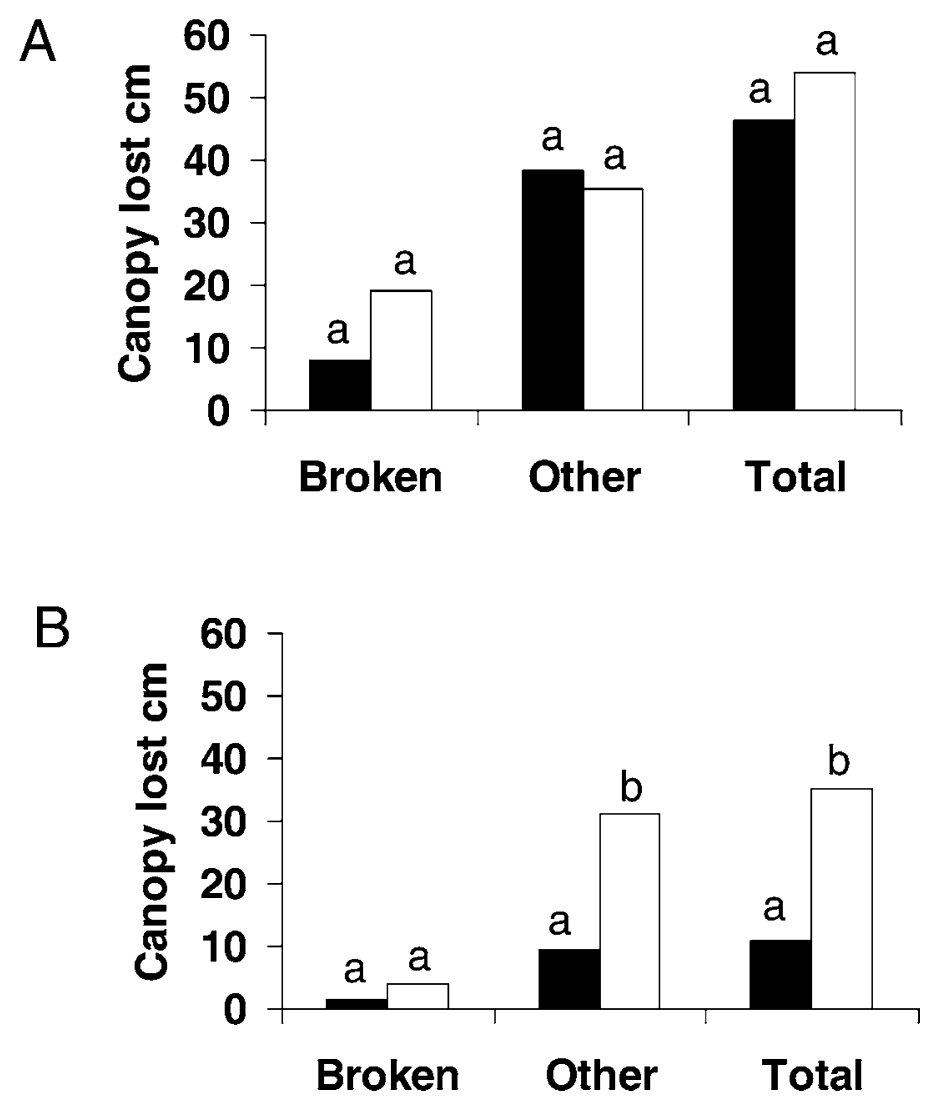

Figure 1. Mountain big sagebrush (A) or antelope bitterbrush (B) canopy lost to breakage, other causes, and all causes from ewes with a low (black bars) or high (white bars) preference for mountain big sagebrush. Within a category, bars with different letters are significantly different $(P<0.05)$. For panel $\mathrm{A}, \mathrm{SE}=6.3,8.1$, and 9.6 for broken, other, and total, respectively. For panel $B, S E=2.8,3.7$, and 4.0 for broken, other, and total, respectively. 


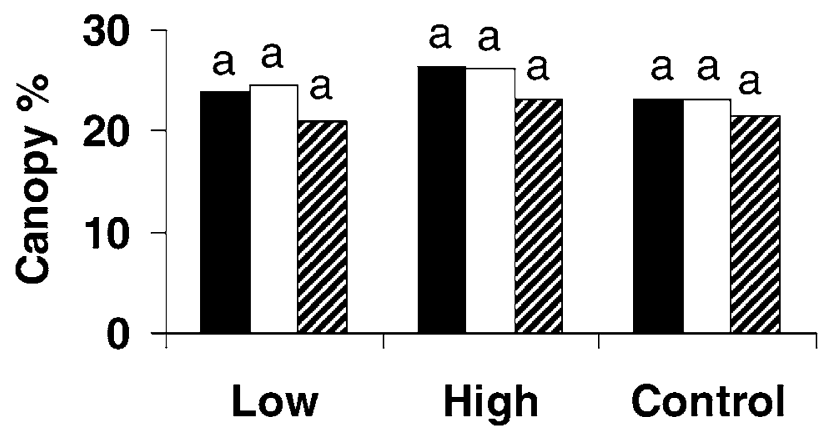

Treatment

B

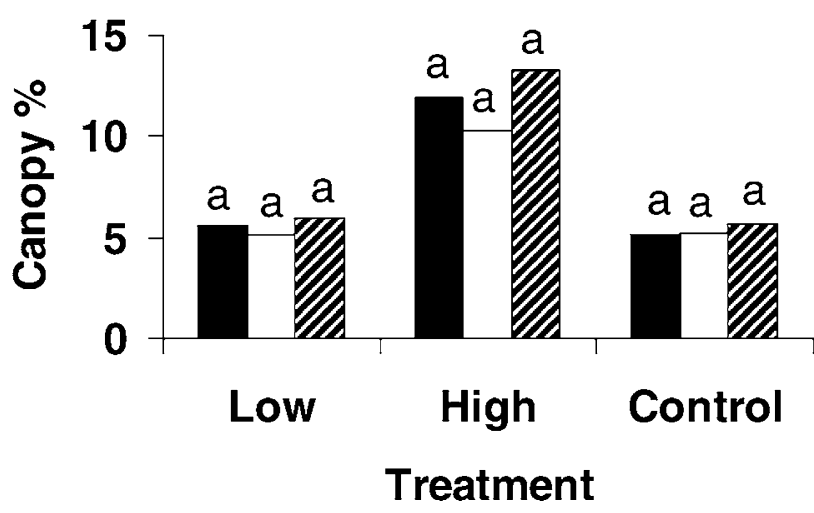

Figure 2. Change in percent canopy of mountain big sagebrush $(\mathbf{A})$ or antelope bitterbrush (B) canopy from 2001 (black bars), 2002 (white bars), and 2003 (diagonal stripes) in pastures grazed by ewes with a low or high preference for mountain big sagebrush and in pastures that were not grazed. For panel $A, S E=3.0,2.5$, and 3.1 for 2001, 2002, and 2003 , respectively. For panel $B, S E=2.3,2.1$, and 2.3 for 2001, 2002, and 2003, respectively.

of antelope bitterbrush canopy by the ewes with a high preference for sagebrush $(P<0.12)$.

Although mountain big sagebrush canopy declined in the grazing treatments, the reduction did not differ from the reduction of the canopy in the control pastures (Fig. 2a). Mountain big sagebrush decreased in all three treatments from 2001 to 2003. Antelope bitterbrush cover did not change over the course of the experiment despite sheep utilization (Fig. 2b).

\section{DISCUSSION}

Three years of fall sheep grazing did not change shrub canopies of mountain big sagebrush or antelope bitterbrush compared with ungrazed pastures. Ewes selected for a dietary preference for mountain big sagebrush did not reduce sagebrush canopies more than ewes with a reduced dietary preference for mountain big sagebrush (Fig. 2a). However, ewes with a dietary preference for mountain big sagebrush consumed more antelope bitterbrush than did the ewes with a reduced dietary preference for mountain big sagebrush (Fig. 2b).

Mountain big sagebrush consumption from both classes of ewes decreased approximately $50 \%$ each year during the 3 years of the study (Table 2). Two possible reasons for this decline in consumption are the increasing age of the ewes and changes in mountain big sagebrush palatability. Ewes on average were 7 years old at the end of the study and might have had progressive problems with teeth wearing or breakage that could have reduced their preference for sagebrush. This reduction in consumption might also result from changes in palatability because of successive years of reduced precipitation, which might have increased terpene content (Scholl et al. 1977), although terpene content was not measured. This reduction in plant growth might have resulted in a reduced availability or accessibility of preferred plant parts because of the previous years' utilization (i.e., hedging).

Brush cover was measured along permanent transects with the reasoning that change in the canopy diameter would be more accurately measured. In fact, it was thought that the data would provide indications of what caused changes to canopy diameters along the transect for each individual plant over the course of the study, allowing repeated measures of growth rates and canopy expansion and contraction. Unfortunately, the winter snow pack (up to $1 \mathrm{~m}$ deep) broke branches every year and spread out the remaining canopy enough that it was impossible to follow individual plants through the 3 years of the study in a manner that would permit determination of grazing effects on the canopy of individual shrubs. In addition, mountain big sagebrush has a growth form in which almost all terminal branches grow upward from a more horizontal stem (personal observation). Herbivory of this plant can remove much of the tops of these branches without reducing canopy diameter. In contrast, antelope bitterbrush expands its canopy in a more horizontal direction (personal observation), making reductions of canopy from herbivory more easily observed and measured.

Livestock with a genetic or learned disposition for a specific diet could have application for vegetation management designed to alter a plant community to one that is richer in native plants or that is more sustainable (Snowder et al. 2001). During the 3 years of this study, sheep grazing did not reduce overall shrub cover on lands with a dense cover of shrubs. Any loss in shrub cover appeared to be from natural forces, such as reduced precipitation and any wildlife grazing that occurred. If the study had been continued for another decade, it is possible that differences among the treatments would have occurred (Bork et al. 1998); however, long-term high-intensity sheep grazing is not practical for the millions of hectares of rangelands that have overly dense stands of mountain big sagebrush because of low numbers of domestic sheep.

\section{MANAGEMENT IMPLICATIONS}

Although ewes with a high preference for mountain big sagebrush did not reduce sagebrush canopy more than ewes with a low preference for mountain big sagebrush, highpreference ewes had a greater preference for antelope bitterbrush than low-preference ewes. Because antelope bitterbrush is considered an important plant species in western rangelands (Bishop et al. 2001; Clements and Young 2001), the increased utilization of antelope bitterbrush by ewes with a high preference for mountain big sagebrush is a negative consequence of animal selection. In this study, the increased utilization of antelope bitterbrush by ewes with a high preference for 
sagebrush did not result in a decrease in its canopy, which might reflect an ability to recover from grazing pressure (Ganskopp et al. 2004). Many products and technologies have come with unintended consequences, which are only discovered years after their widespread introduction (Norman 1981). The genetics of diet selection is complex, and this study confirms that diet preference for one plant species can result in a diet preference for another plant species with potential negative consequences for plant communities and ecosystems.

\section{ACKNOWLEDGMENTS}

The author expresses his appreciation to Dr John Walker, Scott McCoy, Mark Williams, Dave Swanson, Ella Ybarlucea, Joel Billman, Brad Eddins, Jack Hensley, and Lyn Mortensen for their technical assistance.

\section{LITERATURE CITED}

Bishop, C. J., E. O. Garton, And J. W. Unsworth. 2001. Bitterbrush and cheatgrass quality on 3 southwest Idaho winter ranges. Journal of Range Management 54:595-602.

Blaisdell, J. P., R. B. Murray, and E. D. McArthur. 1982. Managing intermountain rangelands - sagebrush-grass ranges. Ogden, UT: US Department of Agriculture Forest Service, Intermountain Research Station General Technical Report INT-134. 41p.

Bork, E. W., N. E. WeSt, AND J. W. WaLkER. 1998. Cover components on long-term seasonal sheep grazing treatments in three-tip sagebrush steppe. Journal of Range Management 51:293-300.

Clements, C. D., and J. A. Young. 2001. Antelope bitterbrush seed production and stand age. Journal of Range Management 54:269-273.

Ganskopp, D., T. Svejcar, F. Taylor, and J. Farstvedt. 2004. Can spring cattle grazing among young bitterbrush stimulate shrub growth? Journal of Range Management 57:161-168.

Grant, S. A., D. E. Suckling, H. K. Smith, L. Torvell, T. D. A. Forbes, and J. Hodgson. 1985. Comparative studies of diet selection by sheep and cattle: the hil grasslands. Journal of Ecology 73:987-1004.

HaRnISS, R. O., AND R. B. MuRRAY. 1973. 30 years of vegetal change following burning of sagebrush-grass range. Journal of Range Management 26:322-325.
Johnson, K. H., R. A. OLson, And T. D. Whitson. 1996. Composition and diversity of plant and small mammal communities in tebuthiuron-treated big sagebrush (Artemisia tridentata). Weed Technology 10:404-416.

Launchbaugh, K. L., J. W. Stuth, and J. W. Holloway. 1990. Influence of range site on diet selection and nutrient intake of cattle. Journal of Range Management 43:109-116.

Milne, J. A., L. Bagley, and S. A. Grant. 1979. Effects of season and level of grazing on the utilization of heather by sheep. 2. Diet selection and intake. Grass Forage Science 34:45-53.

Norman, C. 1981. The god that limps: Science and technology in the eighties. New York, NY: World Watch Press, W. W. Norton \& Co, Inc. 224 p.

[NRCS] Natural Resources Conservation Service. 1995. Soil investigation of Agriculture Research Service, United States Sheep Experiment Station headquarters range, US Department of Agriculture. Rexburg, ID: NRCS. $133 \mathrm{p}$.

Olson, B. E., R. T. Wallander, V. M. Thomas, and R. W. Kott. 1996. Effect of previous experience on sheep grazing leafy spurge. Applied Animal Behaviour Science 50:161-176.

ProvenzA, F. D. 1996. Acquired aversions as the basis for varied diets of ruminants forageing on rangelands. Journal of Animal Science 74:2010-2020.

Scholl, J. P., R. G. Kelsey, and F. Shafizadeh. 1977. Involvement of volatile compounds of Artemisia in browse preference by mule deer. Biochemical Systematics and Ecology 5:291-295.

Snowder, G. D., J. W. Walker, K. L. Launchbaugh, and L. D. Van Vleck. 2001. Genetic and phenotypic parameters for dietary selection of mountain big sagebrush (Artemisia tridentata Nutt. ssp. vaseyana [Rydb] Beetle) in Rambouillet sheep. Journal of Animal Science 79:486-492.

Walker, J. W., K. J. Hemenway, P. G. Hatfield, and H. A. Glimp. 1992. Training lambs to be weed eaters: studies with leafy spurge. Journal of Range Management 45:245-248.

Walker, J. W., S. L. Kronberg, S. L. Al-Rowaily, and N. W. West. 1994. Comparison of sheep and goat preferences for leafy spurge. Journal of Range Management 47:429-434.

Warren, L. M., D. N. UeCKert, and G. D. Snowder. 1983. Influence of heredity on the selection of various forage species by goats. College Station, TX: Texas A\&M University, Texas Agriculture Experiment Station CPR 4171. p 72-81.

WEST, N. E. 1983. Western intermountain sagebrush steppe. In: N. E. West [ed.]. Ecosystems of the world 5: Temperate deserts and semi-deserts. New York, NY: Elsevier Science Publishing. p 351-397.

Winder, J. A., D. A. Walker, AND C. C. Balley. 1995. Genetic aspects of diet selection in the Chihuahuan desert. Journal of Range Management 48:549-553. 